九州大学学術情報リポジトリ

Kyushu University Institutional Repository

\title{
Temporal Effects of High Dietary Zinc on the Histological Changes Produced in White Leghorn Cocks
}

El tohamy, Magda Mohammed

Laboratory of Animal Husbandry II, Faculty of Agriculture, Kyushu University

Takahara, Hitoshi

Laboratory of Animal Husbandry II, Faculty of Agriculture, Kyushu University

Okamoto, Masao

Laboratory of Animal Husbandry II, Faculty of Agriculture, Kyushu University

https://doi.org/10.5109/23709

出版情報: 九州大学大学院農学研究院紀要. 24 (4)，pp. 189-199，1980-02. Kyushu University バージョン：

権利関係 : 
J. Fac. Agr., Kyushu Univ., 24(4), 189-199 3 pls. (1980)

\title{
Temporal Effects of High Dietary Zine on the Histological Changes Produced in White Leghorn Cocks
}

\author{
Magda Mohammed Eltohamy, Hitoshi Takahara \\ and Masao Okamoto \\ Laboratory of Animal Husbandry II, Faculty of Agriculture, \\ Kyushu University 46-96, Fukuoka 812
}

(Received September 19, 1979)

\begin{abstract}
Effects of high dietary $\mathrm{Zn}$ on histological changes of the endocrine glands were investigated in White Leghorn cocks. Cocks received $1000 \mathrm{ppm}$ dietary $\mathrm{Zn}$ showed normal testicular development. In the groups received 3000 and $4000 \mathrm{ppm}$ dietary $Z_{n}$, the inhibitory effects in the testes suggested impaired production and/or release of adenohypophysial gonadotrophic hormone. Adenohypophysis of the group received $1000 \mathrm{ppm}$ dietary $\mathrm{Zn}$ showed an increase in PAS-positive materials of the basophils, while adenohypophysis of the groups received 3000 and $4000 \mathrm{ppm}$ dietary $\mathrm{Zn}$ showed the marked regressive changes. In these morphological changes, evidence of diminished cellular activity support the morphological changes detected in the testes. Caudal acidophils of the group received $1000 \mathrm{ppm}$ dietary $\mathrm{Zn}$ increased in number and size, while the acidophils of the groups received 3000 and $4000 \mathrm{ppm}$ dietary $\mathrm{Zn}$ decreased in number and size. These changes might illustrate to interfere with somatic growth. Amphophils of the cephalic lobe were in an artive functional phase in all groups received $\mathrm{Zn}$. Histololgical and histochemical changes in the adrenals, reflected in cortical hypertrophy and increase lipid and cholesterol contents in the cortex, were indication of active adrenals in all groups received $\mathrm{Zn}$. Thyroid glands were more resistant to high levels of dietary $\mathrm{Zn}$. Pancreas of the group received $1000 \mathrm{ppm}$ dietary $\mathrm{Zn}$ was unaltered, while the glands in the groups received 3000 and $4000 \mathrm{ppm}$ dietary $Z n$ were markedly changed in both exocrine and endocrine portions. After 2 weeks of recovery period, the testes, adenohypophysis, adrenals and pancreas restored to normal condition. Therefore, the results led to assumption that $\mathrm{Zn}$ has direct effect not only on the testes, adenohypophysis but may be also on the adrenals, while the thyroids were resistant to $\mathrm{Zn}$ addition.
\end{abstract}

\section{INTRODUCTION}

The indispensability of $\mathrm{Zn}$ for normal reproductive processes in human and animals is well documented. Several organs with endocrine function such as thyroids, adrenals, testes and pancreas in the rat show a relatively high uptake of ${ }^{65} \mathrm{Zn}$. The role of $\mathrm{Zn}$ in the normal function of the male genital tract has been demonstrated (Miller et al., 1958). Mawson and Fischer (1953) reported that semen and spermatozoa were rich sources of $\mathrm{Zn}$. Therefore, $\mathrm{Zn}$ seems to have a particular role in the physiological function of the testes. Testicular $\mathrm{Zn}$ metabolism has been shown to be regulated under the control of pituitary gland. Hypophysectomy depresses radiozinc uptake of the 
testes in the rats and interstitial cell stimulating hormone (ICSH) administration prevents the fall of radiozinc uptake (Gunn et al., 1961).

Pancreas is one of the organs in which the most rapid accumulation and turnover of retained $\mathrm{Zn}$ occurs (Feaster et al., 1954). Pancreatic acinar cells are known to be a major excretion pathway of $\mathrm{Zn}$ (Montgomery et al., 1943). Since $Z n$ is believed to play a direct role in protein synthesis, some abnormalities of pancreatic exocrine function might be predicted when this organ supplied with inadequate $\mathrm{Zn}$.

Growth retardation, anemia and disturbance in tissue levels of several essential minerals were produced by high levels of dietary $\mathrm{Zn}$ (Grant-Frost and Underwood, 1958). The adverse physiological effects produced by high dietary $\mathrm{Zn}$ in rats have been attributed to reduce food intake. Previous morphological studies demonstrated that the adverse physiological effects of high dietary $\mathrm{Zn}$ on the testes of cockerels might be due to endocrine mechanism (Eltohamy et al., 1979). But the significance and exact nature of the hormonal control involvement which accompanies with the administration of dietary $\mathrm{Zn}$ are still unknown in the cocks.

The present study was undertaken in order to gain background information necessary for evaluationg the effects of high dietary $\mathrm{Zn}$ in mature cocks, to define and correlate the morphological changes in the testes, adenohypophysis, adrenals, thyroids and pancreas, to elucidate the role of high dietary $\mathrm{Zn}$ on the adenohypophysis-gonadal axis and to assess whether or not the adverse physiological effects of high dietary $\mathrm{Zn}$ can recover when the cocks fed diet without added $\mathrm{Zn}$.

\section{MATERIALS AND METHODS}

Twelve-weeks old, 48 White Leghorn cocks were randomly divided into four experimental groups of 12 cocks each. One group was fed a basal diet (Table 1) which contained $80 \mathrm{ppm} \mathrm{Zn}$. Three other groups were fed the diets to which $\mathrm{Zn}$ ammonium sulphate was added at levels of 1000,3000 and 4000 ppm. The diets and water were offered ad libitum. Body weights were recorded at 7 days intervals. At the end of 25 days experimental periods, 24 cocks (6 cocks from each experimental group) were sacrificed by decapitation. As rapidly as possible, testes, adenohypophysis, adrenals, thyroids and pancreas were removed, weighed and used for $\mathrm{Zn}$ analysis and histological examination.

$\mathrm{Zn}$ contents of the diet and individual organs were determined by atomic absorption spectrophotometry after wet digestion of samples in the nitric perchloric acids mixture. $\mathrm{Zn}$ content was calculated as $\mathrm{Zn}$ concentration on fresh weight basis.

The adenohypophysis was fixed in sublimate-formol and stained with Matsuo tetrachrome method and periodic acid-Schiff (PAS) method. The testes and thyroids were fixed in Bouin's solution and stained with hematoxylineosin (HE) and PAS-hematoxylin. The adrenals and pancreas were fixed in $10 \%$ formalin and stained with HE. Frozen sections of the adrenals were 
Table 1. Composition of the basal diet.

\begin{tabular}{lr}
\hline Ingredient & $(\%)$ \\
\hline Corn & 24.0 \\
Barley & 50.5 \\
Soybean & 7.0 \\
Fish meal & 18.0 \\
Sodium chloride & 0.5 \\
\hline
\end{tabular}

stained with Sudan black for lipoid. The schultz test for cholesterol were also performed. The other 24 cocks (the remainder 6 cocks from each experimental group) were placed on the diets without addition of $\mathrm{Zn}$ for 2 weeks recovery period and then sacrificed. This was done in order to find out whether or not the cocks could recover from the high levels of $\mathrm{Zn}$.

\section{RESULTS}

\section{Body and organ weights}

Data illustrating the effects of high dietary $\mathrm{Zn}$ on body, testes, adenohypophysis, adrenals, thyroids and pancreas weights found in experimental and recovery periods are presented in Table 2 . The level of $1000 \mathrm{ppm}$ dietary $\mathrm{Zn}$ caused slight increase in body weight of the cocks over that of control, but the difference was not significant. Significant depression of body weight occurred only with the level of $4000 \mathrm{ppm}$ dietary $\mathrm{Zn}$. For the recovery period,

Table 2. Effects of high dietary $\mathrm{Zn}$ levels on body and organ weights for the experimental and recovery periods.

\begin{tabular}{|c|c|c|c|c|c|c|}
\hline $\begin{array}{l}\mathrm{Zn} \text { added } \\
\text { to the diet } \\
(\mathrm{ppm})\end{array}$ & $\begin{array}{l}\text { Body } \\
\text { weight } \\
\text { (g) }\end{array}$ & $\begin{array}{c}\text { Adenohypo- } \\
\text { physis } \\
\text { weight } \\
\text { (mg) }\end{array}$ & $\begin{array}{c}\text { Adrenals } \\
\text { weight } \\
\text { (mg) }\end{array}$ & $\begin{array}{l}\text { Thyroids } \\
\text { weight } \\
\text { (mg) }\end{array}$ & $\begin{array}{l}\text { Pancreas } \\
\text { weight } \\
\text { (g) }\end{array}$ & $\begin{array}{l}\text { Testes } \\
\text { weight } \\
\text { (g) }\end{array}$ \\
\hline \multicolumn{7}{|c|}{ Experimental period } \\
\hline $\begin{array}{r}0 \\
1000 \\
3000 \\
4000\end{array}$ & $\begin{array}{c}1782.00 * \\
\pm 112.56 \\
1815.00 \\
\pm 161.12 \\
1746.00 \\
\pm 163.95 \\
1443.571 \\
+252.07\end{array}$ & $\begin{aligned} & 12.70 * \\
& \pm 3.00 \\
& 13.75 \\
& \pm 2.24 \\
& 13.14 \\
& \pm \quad 3.44 \\
& 9.80 \\
& \pm \quad 4.26\end{aligned}$ & $\begin{aligned} & 183.28^{*} \\
& \pm 35.30 \\
& 197.87 \\
& \pm 30.30 \\
& 181.52 \\
& \pm \quad 30.33 \\
& 174.00 \\
& \pm \quad 42.10\end{aligned}$ & $\begin{array}{r}166.00 * \\
\pm \quad 45.60 \\
168.00 \\
\pm \quad 36.30 \\
142.80 \\
\pm \quad 45.90 \\
169.60 \\
\pm 98.40\end{array}$ & $\begin{aligned} & 3.11 * \\
& \pm 0.70 \\
& 3.11 \\
& \pm 0.29 \\
& 3.03 \\
& \pm 0.60 \\
& 2.18 \\
& \pm 0.71\end{aligned}$ & $\begin{aligned} & 20.97 * \\
\pm & 4.46 \\
& 21.10 \\
\pm & 6.04 \\
& 8.75 \\
\pm & 4.52 \\
& 0.88^{1)} \\
\pm & 0.93\end{aligned}$ \\
\hline \multicolumn{7}{|c|}{ Recovery period } \\
\hline $\begin{array}{r}0 \\
1000 \\
3000 \\
4000\end{array}$ & $\begin{array}{r}1790.00 \\
\pm \quad 51.96 \\
1860.00 \\
\pm \quad 45.83 \\
1890.00 \\
\pm \quad 27.07 \\
1862.50 \\
\pm \quad 69.46\end{array}$ & $\begin{array}{r}10.70 \\
\pm 0.71 \\
11.53 \\
\pm 0.35 \\
12.05 \\
\pm \quad 1.63 \\
10.83 \\
\pm 0.88\end{array}$ & $\begin{array}{r}140.00 \\
\pm \quad 53.00 \\
124.17 \\
\pm 33.26 \\
219.15 \\
\pm 35.14 \\
185.50 \\
\pm 25.44\end{array}$ & $\begin{array}{r}146.10 \\
\pm \quad 46.10 \\
192.50 \\
\pm 49.32 \\
147.75 \\
\pm \quad 44.48 \\
168.52 \\
\pm 55.51\end{array}$ & $\begin{array}{r}3.03 \\
\pm 0.56 \\
3.23 \\
\pm 0.33 \\
3.45 \\
\pm 0.51 \\
3.11 \\
\pm 0.63\end{array}$ & $\begin{array}{c}30.22 \\
\pm \quad 2.39 \\
29.99 \\
\pm \quad 1.39 \\
27.07^{11} \\
\pm 0.33 \\
26.01^{1)} \\
\pm \quad 7.86\end{array}$ \\
\hline
\end{tabular}

* Mean value \pm standard error. 1) Significantly different $(\mathrm{P}<0.01)$ from control group by analysis of variance. 
the body weights were essentially the same for the three groups supplemented dietary $\mathrm{Zn}$ and they were slightly larger than that of normal control. Organ weights of all groups were not affected by the addition of $\mathrm{Zn}$ to the diet except the testes. Comparison of organ weights data obtained within groups showed that the only significant change was a decrease in testes weights of the group received $4000 \mathrm{ppm}$ dietary $\mathrm{Zn}$. With the exception of the testes, no differences were found between the three groups and control in organ weights after the recovery period.

\section{Tissue $\mathrm{Zn}$ concentration}

Data showing $\mathrm{Zn}$ concentration on wet weight basis of testes, adenohypophysis, adrenals, thyroids and pancreas are tabulated in Table 3. No significant differences were found between experimental groups and their control in $\mathrm{Zn}$ concentration of the testes, the trend indicated higher values in the group received $4000 \mathrm{ppm}$ dietary $\mathrm{Zn}$. As the levels of dietary $\mathrm{Zn}$ increased, a corresponding increase in $\mathrm{Zn}$ concentration of adrenals was detected. Adrenals of the group received $4000 \mathrm{ppm}$ dietary $\mathrm{Zn}$ contained a significantly higher concentration of $\mathrm{Zn}$ than that of the control. $\mathrm{Zn}$ concentrations in the thyroids of the groups received the levels of 1000 and $3000 \mathrm{ppm}$ dietary $\mathrm{Zn}$ were higher than that of the control, but the data were statistically not significant. The high level of $4000 \mathrm{ppm}$ dietary $\mathrm{Zn}$ reduced the concentration of $\mathrm{Zn}$ in the thyroids but the reduction was not significant. The same trend occurred in the pancreas but the magnitude was higher in pancreas than that in the

Table 3. Effects of high dietary $\mathrm{Zn}$ levels on $\mathrm{Zn}$ concentration of testes, adrenals, thyroids and pancreas.

\begin{tabular}{|c|c|c|c|c|}
\hline \multirow{2}{*}{$\begin{array}{c}\mathrm{Zn} \text { added to } \\
\text { the diet } \\
(\mathrm{ppm})\end{array}$} & \multicolumn{4}{|c|}{ Tissue $Z_{n}$ concentration } \\
\hline & Testes (ppm) & Adrenals (ppm) & Thyroids (ppm) & Pancreas (ppm) \\
\hline \multicolumn{5}{|c|}{ Experimental period } \\
\hline $\begin{array}{r}0 \\
1000 \\
3000 \\
4000\end{array}$ & $\begin{array}{r}12.83^{*} \\
\pm \quad 1.53 \\
12.29 \\
\pm \quad 1.04 \\
15.62 \\
\pm \quad 2.90 \\
22.09 \\
\pm 2.09\end{array}$ & $\begin{array}{c}32.34^{*} \\
\pm \quad 6.90 \\
69.34^{2)} \\
\pm 25.53 \\
74.41 \\
\pm 10.26 \\
59.62^{1)} \\
\pm 16.90\end{array}$ & $\begin{array}{r}57.40^{*} \\
\pm 25.31 \\
69.61 \\
\pm 31.38 \\
71.80 \\
\pm 24.94 \\
47.00 \\
\pm 16.21\end{array}$ & 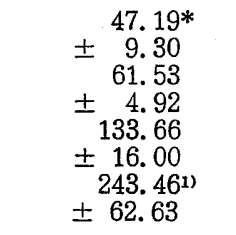 \\
\hline \multicolumn{5}{|c|}{ Recovery period } \\
\hline $\begin{array}{r}0 \\
1000 \\
3000 \\
4000\end{array}$ & $\begin{array}{c}12.03 \\
\pm 0.28 \\
11.53 \\
\pm 0.38 \\
10.50^{2)} \\
\pm 1.78 \\
11.40^{2)} \\
\pm 1.69\end{array}$ & $\begin{array}{r}45.93 \\
\pm 14.60 \\
64.01 \\
\pm 12.21 \\
42.49 \\
\pm \quad 6.69 \\
52.27 \\
\pm \quad 6.59\end{array}$ & $\begin{array}{r}80.35 \\
\pm 26.55 \\
67.43 \\
\pm 25.43 \\
60.44 \\
\pm 16.50 \\
46.82^{11} \\
\pm 7.18\end{array}$ & $\begin{array}{r}37.36 \\
\pm \quad 9.99 \\
42.59 \\
\pm \quad 4.99 \\
36.15 \\
\pm \quad 4.65 \\
40.91 \\
\pm \quad 7.83\end{array}$ \\
\hline
\end{tabular}

* Mean value \pm standard error. "Significantly different $(\mathrm{p}<0.01)$ from the control group by analysis of variance. 2) Significantly different $(p<0.05)$ from the control group by analysis of variance. 
adrenals.

With the exception of the testes of the groups received the levels of 3000 and $4000 \mathrm{ppm}$ dietary $\mathrm{Zn}$, no significant changes were detected in $\mathrm{Zn}$ concentration of all organs after the recovery period.

\section{Histological changes}

Histological examination of the testes revealed that the seminiferous tubules in the group receiving $1000 \mathrm{ppm}$ dietary $\mathrm{Zn}$ had normal development. The majority of the tubules contained spermatids in advanced stages of development and spermatozoa and they were presented in a large percentage of tubules (P1. III-Fig. 2). Seminiferous tubules diameter remained within normal limits. The interstitial cells were not increased. The testes from the group receiving $3000 \mathrm{ppm}$ dietary $\mathrm{Zn}$ exhibited a delay in spermatogenesis. All of the seminiferous tubules were reduced in size as compared with that of the control, but not so seriously reduced as that of the group receiving $4000 \mathrm{ppm}$ dietary $\mathrm{Zn}$. In most of the tubules, spermatogenesis had not proceeded beyond the stage of primary spermatocytes. The interstitial cells were increased in number and size. The most noticeable effect of dietary $\mathrm{Zn}$ was evident in the seminiferous tubules of the group receiving $4000 \mathrm{ppm}$ dietary $\mathrm{Zn}$ (P1. IIIFig. 3. Compare with P1. III-Fig. 1). They were markedly diminished in diameter and often irregular in contour. In all tubules the normal sequence in spermatogenesis was impaired. Spermatids and spermatozoa were completely absent in most tubules. Only Sertoli cells and spermatogonia were presented in seemingly good condition. There were hyperplasia in the interstitial cells. The interstitial tissue condensed possibly due to shrinkage of the seminiferous tubules. No obvious changes were detected in histological feature after the recovery period ( $\mathrm{Pl}$. III-Fig. 4).

Increased amount of PAS-positive materials of the basophils were apparent in the adenohypophysis of the group receiving $1000 \mathrm{ppm}$ dietary $\mathrm{Zn}$. This level did not appear to increase the number and size of the basophils. On the contrary, the number and size of the acidophils in caudal lobe were increased and the cytoplasmic granules stained intensely with orange $G$ in these cells (P1. IV-Fig. 6. Compare with Pl. IV-Fig. 5). The amphophils of the cephalic lobe increased distinctly in number, enlarged in size and occupied large area of the cephalic lobe. The enlarged amphophils were polygonal in shape with a large nucleus and contained faint granules which stained weakly with PAS method (P1. IV-Fig. 9. Compare with Pl. IV-Fig. 8). These enlarged cells suggest an active functional phase of the cells.

Adenohypophysis of the group receiving $3000 \mathrm{ppm}$ dietary $\mathrm{Zn}$ showed slight reduction in number and size of the basophils. PAS-positive materials were diminished. Some vacuoles occurred in these cells and may be inactive in hormone production. The acidophils appeared to be decreased in number and smaller in size than that in the group receiving $1000 \mathrm{ppm}$ dietary $\mathrm{Zn}$, but they were larger in number than that in normal control. The amphophils were identical to those found in the group receiving 1000 ppm dietary $Z n$ except slight reduction in number. 
The effects of $4000 \mathrm{ppm}$ dietary $\mathrm{Zn}$ were marked in the adenohypophysis (P1. IV-Figs. 7 and 10). Many of the basophils were shrunken and their cytoplasms were depleted of secretory granules, so that they were difficult to distinguish from chromophobes. The basophils also showed marked regressive changes, such as vacuolation of the cytoplasm, pyknosis of the nuclei and degranulation. There was marked reduction in size of the acidophils as compared with that in other experimental groups. They stained very lightly with orange G. The amphophils were enlarged to some extent and increased in number as compared with that in other groups. The cell boundaries were often less distinct. These morphological changes in the adenohypophysis of the cocks receiving $4000 \mathrm{ppm}$ dietary $\mathrm{Zn}$ support the morphological changes in the testes as described previously. After the recovery period, the cellular activities were restored to normal condition in all groups.

In the group receiving $1000 \mathrm{ppm}$ dietary $\mathrm{Zn}$, the adrenal cortex was larger than that in the control. Hypertrophied cortex showed enlargement of the component cells throughout the gland. In addition to this, they reacted strongly with Sudan black and showed considerably more lipid as compared with that in the control (P1. V-Figs. 13 and 14). Schultz cholesterol test was strongly positive for the hypertrophied cortex which suggested an increase in the cholesterol content. Concurrent with the cellular hypertrophy in the cortex, there was degranulation in the medullary cells. Adrenals of both groups receiving the levels of 3000 and $4000 \mathrm{ppm}$ dietary $Z \mathrm{n}$ showed hypertrophy in the cortex as compared with that in the control (Pl. V-Fig. 15). A decrease in medullary cell granulation occurred in the groups received 3000 and 4000 ppm dietary $\mathrm{Zn}$.

Histological examinations of the thyroids revealed no differences between groups were detected, indicating that these organs are more resistant to the changes in the levels of high dietary $\mathrm{Zn}$.

Pancreatic tissue of the group receiving $1000 \mathrm{ppm}$ dietary $\mathrm{Zn}$ appeared to be morphologically normal. There were well developed acini and numerous islets of Langerhans of various size which were characteristic of this gland. $\alpha$ - and $\beta$-cells in the islets were heavily granulated. The acinar cells of the group receiving $3000 \mathrm{ppm}$ dietary $\mathrm{Zn}$ were small, poor in cytoplasm and contained small densely granulated areas at the apical position of the cells. The islets of this group appeared to decrease in number and enlarged in size in comparison with that in control. Marked changes in the acini and islets of the pancreas of the group receiving $4000 \mathrm{ppm}$ dietary $\mathrm{Zn}$ were observed ( $\mathrm{Pl}$. V-Fig. 17. Compare with Fig. 16). The acinar cells showed loss of zymogen and other cytoplasmic granules. Well developed connective tissue were found between the acini. In some parts, scattered acinar cells could be identified in the fibrous stroma and contained zymogen like granules. Some vacuoles appeared in these cells. The nuclei of these cells were stained strongly with $\mathrm{HE}$ stain. The islets of this group were enlarged and had irregular outlines but $\beta$-cells appeared to be larger than those of normal control and somewhat degranulated. After recovery period, the cytoplasmic granules in the acinar cells increased and the normal activity might reappeared in all groups. Signs 
of recovery of all groups were observed in the acinar and islet cells histologically.

\section{DISCUSSION}

The results of the present study indicate that the cocks tolerated the levels of 1000 and $3000 \mathrm{ppm}$ dietary $Z n$ without adverse effect. While the level of $4000 \mathrm{ppm}$ dietary $\mathrm{Zn}$ adversely affected growth. Various factors that might contribute to poor growth with high levels of dietary $\mathrm{Zn}$ were enumerated and discussed (Roberson and Schaible, 1960; Johnson et al., 1962). Besides these factors, the reduction of pituitary growth hormone secretion may be added, this assumption was supported by reduction in number and size of acidophils of the adenohypophysis in the present study (discussed later).

Spermatogenesis was qualitatively normal in the cocks received the level of $1000 \mathrm{ppm}$ dietary $\mathrm{Zn}$, as shown by the appearance of large numbers of mature spermatozoa in this study. Although the cockerels received the same level of dietary $\mathrm{Zn}$ from one day old to maturity did not show normal testicular development but a damage of seminiferous tubules and also germinal cells were observed (Eltohamy et al., 1979). The possible explanation of these findings was that the physiological changes necessary to produce such an effect may be occur within the first 50 days of age. In support of this suggestion, it was found that the testes sensitivity to $\mathrm{Zn}$ appears at certain stage of testicular development. Clermont and Perey (1957) stated that the specific testicular function of $\mathrm{Zn}$ in some relation to the meiotic division began at the time of appearance of the first spermatocytes in rats. Generally, it can be stated that germinal cells of immature cockerels are more susceptible to this level of $\mathrm{Zn}$ than those of adult, $\mathrm{Zn}$ sensitivity decreased with an increase in the age of birds.

Considerable evidence is available which indicates the inhibitory effects of the levels of 3000 and $4000 \mathrm{ppm}$ dietary $\mathrm{Zn}$ on the reproductive function in the cocks. These inhibitory effects reflected in the depression of testes and comb weights and high accumulation of $\mathrm{Zn}$ in the testes. Histological studies of such testes revealed a corresponding inhibition of the maturation division at the stage of spermatocytes resulted in delay of spermatogenesis and hyperplasia of the interstitial cells. These observations were strongly dependent on the levels of dietary $\mathrm{Zn}$, suggested that the levels of dietary $\mathrm{Zn}$ were critical and the levels of 3000 and $4000 \mathrm{ppm}$ used in the present study were excessive. In general, the severity of the effects of these levels of dietary $\mathrm{Zn}$ on the testicular tissue was directly related to the concentration of $\mathrm{Zn}$ in the testes. The marked accumulation of $\mathrm{Zn}$ in the testes from these levels of dietary $\mathrm{Zn}$ may show an excess of $\mathrm{Zn}$ over that required by the testes. This excess of $\mathrm{Zn}$ in the testes may interfere with some factors essential for maintenance of the efficiency of the testes to concentrate $\mathrm{Zn}$ at optimal levels and normal development of spermatogenesis.

Interstitial cells are also susceptible to the high levels of dietary $\mathrm{Zn}$. 
The hyperplasia detected in these cells in the group received the level of $4000 \mathrm{ppm}$ dietary $\mathrm{Zn}$ may be due to temporal loss of testosterone (Lindsey et $a l ., 1969)$. The comb of this group was observed to be paler, less turgid and smaller than those of the other groups, indicating a decrease in androgen activity. In this regard, $\mathrm{Zn}$ was shown under certain conditions to have cancerogenic activity when injected as $5 \%$ solution of sulfate (Gunn et al., 1964). Therefore, it seems that $\mathrm{Zn}$ has effects on spermatogenesis and also on interstitial cells.

The studies of the criteria involved showed that the changes induced by the high levels of dietary $\mathrm{Zn}$ were of a reversible character since each criterion reached a normal level after 2 weeks recovery of $\mathrm{Zn}$. Subsequent decrease in the concentration of the testicular $\mathrm{Zn}$ paralleled further recovery of the germinal epithelium. It is obvious that the germinal epithelium beyond the stage of spermatocytes were not in a state of arrest, since they were able to produce spermatozoa in many of the tubules after the recovery period. On the basis of these observations it is postulated that, there is a defenite delay in the formation of spermatocytes and spermatids and the late stage of spermatids failed to mature. Thus the inhibitory effects of high levels of dietary $\mathrm{Zn}$ on testicular maturation represent transient blockade and the maturation division of the spermatogonia can be considered as the primary site of action by dietary $\mathrm{Zn}$.

From the present results it is assumed that the decrease in $\mathrm{Zn}$ storage in the testes after recovery period may reach the optimum value which is necessary for optimum maturation of the spermatogenesis and then presumably represent a return to normal level. The reversible character of the inhibitory action of the high levels of dietary $\mathrm{Zn}$ may be due to the high degree of resistance of spermatogonia. It is also evident that Sertoli cells are not directly concern with $\mathrm{Zn}$.

In mammals, reptiles and amphibians, the acidophils of the adenohypophysis have been considered to be STH-producing cells (Purves, 1961). In birds there is little evidence for the presence of growth hormone although in domestic fowl it has been recently demonstrated (Harvey and Scanes, 1978). In the present study the acidophils increased in size and number in the adenohypophysis of the cocks received the level of $1000 \mathrm{ppm}$ dietary $\mathrm{Zn}$. It seems that this level of $\mathrm{Zn}$ has stimulating effect on the acidophils of the adenohypophysis. While the regressive changes in these cells of the group received the level of $4000 \mathrm{ppm}$ dietary $Z$ n suggest the inhibitory effects to the secretion of growth hormone. These proposal seem likely in view of the following results. Growth of the cocks received the level of $1000 \mathrm{ppm}$ dietary $\mathrm{Zn}$ was normal and that received the level of $4000 \mathrm{ppm}$ dietary $\mathrm{Zn}$ was reduced.

PAS-positive basophils of the adenohypophysis in the groups received the levels of 3000 and $4000 \mathrm{ppm}$ dietary $\mathrm{Zn}$ were shrunken and partially degranulated. This may indicate reduced gonadotrophic activity of these cells. In PAS staining method, it is difficult to identify the granules in the basophils producing FSH or LH, therefore all basophil granules considered together. The degranulation of the basophils indicates reduced secretion of gonadotrophin. 
Lack of FSH would inhibit spermatogenesis and may result in spermatogenic arrest. While lack of $\mathrm{LH}$ would inhibit androgen secretion of the testes which may result in hypogonadism. The present histological results of the testes are compatible with changes observed in the adenohypophysis. In these results, marked reduction in testes and comb weights and impairment of normal spermatogenesis in the groups received 3000 and $4000 \mathrm{ppm}$ dietary $\mathrm{Zn}$ suggest impaired production and/or release of gonadotrophic hormone of the adenohypophysis. The reduction in number and size and degranulation of PAS-positive basophils of adenohypophysis in the same groups substantiate this.

It is difficult to ascertain whether the reduction of gonadotrophins of the adenohypophysis, which brought about by dietary $\mathrm{Zn}$, is a direct effect of $\mathrm{Zn}$ on adenohypophysis or a secondary effect of the imbalance of the endocrine function induced by $\mathrm{Zn}$ on the testes. The results obtained by capon (Eltohamy et al., unpublished) in which received intramuscular injection of $\mathrm{Zn}$ ammonium sulphate at the level of $10 \mu \mathrm{c} / 100 \mathrm{~g}$ of body weight for 21 days indicated that the basophils of the capon increased in number and size and formed castration cells. These results may contribute to the view that the testes are affected directly by high dietary $Z$ n. Similarly, Shikita and Tamaoki (1963) stated that the loss of ${ }^{65} \mathrm{Zn}$ incorporation by the testes was independent of the pituitary and that its uptake after 24 hours irradiation was related to the interstitial cells. Whereas, Gunn et al. (1961) showed that ICSH plays an important role in the uptake of ${ }^{65} \mathrm{Zn}$ in the mature rat testis. Hypophysectomy depressed ${ }^{65} \mathrm{Zn}$ uptake, and ICSH administration prevented the fall of ${ }^{65} \mathrm{Zn}$ uptake. Therefore, it seems probable that $\mathrm{Zn}$ has direct effect not only on the testes but also on the adenohypophysis.

In normal condition, the amphophils of the cephalic lobe were considered to be the source of adrenocorticotrophic hormone (ACTH) and their PASpositive granules are the carrier substance of ACTH (Mikami, 1958). In the present study, the amphophils were in an active functional phase in all groups receiving $Z \mathrm{n}$, and the storage of PAS-positive granules decreased. Increased ACTH release was also suggested by adrenal hyperplasia. The action of dietary $\mathrm{Zn}$ was amply demonstrated on the adrenals of all groups received $\mathrm{Zn}$. This was shown by elevation of adrenal $\mathrm{Zn}$ concentration, enlargement of the cortical cells, hyperplasia and increase in mitotic activity, lipid and cholesterol content of the cortex. The indications were that the adrenal was active one. These changes closely paralleled the changes seen in the adenohypophysis. The maximum effect was occurred with the level of $4000 \mathrm{ppm}$ dietary $\mathrm{Zn}$. This may be taken, perhaps, to indicate the correlation between adrenal activity and dietary $\mathrm{Zn}$ levels.

The decreased granulation of adrenal medullary cells may lead to the assumption that medullary tissue was also affected by high dietary $\mathrm{Zn}$. It would appear that high dietaty $\mathrm{Zn}$ may inhibit the synthesis or storage of catechol. amines in the medullary granules or accelerate the release of them. It is known that catecholamine promotes the release of adenohypohysial ACTH which in turn stimulates the adrenal cortex.

The mechanism of the stimulation of the adrenals by dietary $\mathrm{Zn}$ was not 
entirely clear, although several possibilities seem tenable. These could result from different sites, including a direct effect on the adrenal cortex or medulla, direct effect on the adenohypophysis control of the secretion of ACTH, or indirect effect via the testes (via steroid feed back). The third possibility seems more likely in which the regressive changes detected in the testes led to development of castration phenomena. In accordance with this, the adrenal changes were observed. In support of this suggestion, Rudzik and Riedel (1960) reported that the incorporation of ${ }^{65} \mathrm{Zn}$ into the testes decreased after adrenalectomy.

The exocrine and endocrine tissues in the pancreas of the group received $1000 \mathrm{ppm}$ dietary $\mathrm{Zn}$ were found to be normal in morphology despite the high concentration of $\mathrm{Zn}$ in this organ was detected. The same level has been reported to induce changes in exocrine portion of the pancreas, but not in the endocrine portion in the immature cockerels (Eltohamy et al., 1979). This leads to a belief that pancreas of mature cock is more resistant to the level of $1000 \mathrm{ppm}$ dietary $\mathrm{Zn}$ than that of the immature cockerels. It is evident that pancreatic tissue involving both acinar and islet cells was affected in the group receiving $4000 \mathrm{ppm}$ dietary $\mathrm{Zn}$. There may be specific inhibition of functional activity in acinar cells and that in $\beta$-cells in endocrine portion. The $\beta$-cells granulation was decreased and in turn insuline production may be diminished. The degranulation of zymogen granules and loss of cytoplasmic basophilia (presumed to reflect the nucleoprotein content of the cell) might construe to inhibition of protein synthesis in the same group. The same observation was seen in the pancreas of rat fed $\mathrm{Zn}$ deficient diet (Holtzer and Van Lancker, 1962). They related these changes to the release of amylase and ribonuclease from the zymogen granules into cytoplasm which were responsible to pancreatic autolysis. The role of high levels of dietary $\mathrm{Zn}$ in these diverse cellular activities was further emphasized by the finding that removal of $\mathrm{Zn}$ from the diet of the cocks was found to produce an increase in the granule contents of the acinar and islets cells and a return to normal condition was occurred. The characteristic arrangement of the parenchyma was restored.

\section{REFERENCES}

Clermont, Y. and B. Perey 1957 Quantitative study of the cell population of the seminiferous tubules in immature rats. Amer. J. Anat., 100: 241-245

Eltohamy, M. M., H. Takahara and M. Okamoto 1979 Effects of dietary $\mathrm{Zn}$ levels on the histological changes produced in White Leghon cockerels. J. Fac. Agr., Kyushu Univ., 24: 11-21

Feaster, J. P., S. L. Hansard, J. T. McCall, F. H. Skipper and G. K. Davis 1954 Absorption and distribution of radiozinc in steers fed high zinc rations. J. Anim. Sci., 13: 781-788

Grant-Frost, D. R. and E. J. Underwood 1958 Zinc toxicity in the rat and its interrelation with copper. Australian J. Exp. Biol. Med. Sci., 36: 339-346

Gunn, S. A., T. C. Gould and W. A. D. Anderson 1961 Hormonal control of $\mathrm{Zn}$ in mature rat testis. J. Endocr., 23: 37-45

Gunn, S. A., T. C. Gould and W. A. D. Anderson 1964 Effect of Zinc on cancerogenesis 
by Cadmium. Proc. Soc. Exp. Med., 115: 653-657

Harvey, S. and C. G. Scanes 1978 The effect of adrenaline and adrenergic antagonists and agonists on growth hormone secretion in the domestic fowl. Gen. Comp. Endoc., 34: $69-70$

Holtzer, R. L. and J. L. Van Lancker 1962 Early changes in pancreatic autolysis. Am. J. Pathol., 40: 331-336

Johnson, D. Jr., L. M. Arnin, Jr., F. X. Savino and H. W. Titus 1962 The tolerance of growing chikens for dietary $\mathrm{Zn}$. Poult. Sci., 41: 311-317

Lindsey, S., C. W. Nichols, G. E. Sheline and I. L. Chaikoff 1969 Leydig cell tumors in rat testes subjected to low dose $\mathrm{X}$ irradiation. Radiat. Res., 40: 366-378

Mawson, C. A. and M. I. Fischer 1953 Zinc and carbonic anhydrase in human semen. Biochem. J., 55: 669-672

Mikami, S. 1958 The cytological significance of regional patterns in the adenohypophysis of the fowl. J. Agr., Iwate Univ., 3: 473-545

Miller, M. J., P. V. Elcoate, M. I. Fischer and C. A. Mawson 1958 The effects of dietary $\mathrm{Zn}$ deficiency on reproductive system of male rats. Can. J. Biochem. Physiol., 36: 557569

Montgomery, M. L., G. E. Sheline and I. L. Chaikoff 1943 The elimination of administrated zinc in the pancreatic juice, duodenal juice, and bile of the $\mathrm{dog}$ as measured by its radioactive isotope $\left(\mathrm{Zn}_{\mathrm{n}}-65\right)$. J. Exp. Med., 78: 151-159

Purves, H. D. 1961 Morphology of the hypophysis related to its function. In "Sex and Internal Secretion", Vol. 1, ed. by W. C. Young, Williams and Wilkins, Baltimore, pp. 161-239

Roberson, R. H. and P. J. Schaible 1960 The tolerance of growing chicks for high levels of different forms of zinc. Poult. Sci., 39: 893-896

Rudzik, A. D. and B. E. Riedel 1960 The effect of adrenalectomy and cortisone on zinc metabolism in the sex glands and adrenal of the male rat. Can. J. Biochem. Physiol., 38: $845-851$

Shikita, M. and B. Tamaoki 1963 Influence of X irradiation on zinc-65 uptake of the testes in mice. Radiat. Res., 19: 419-428 


\section{Explanation of Plate III}

Fig. 1. Testis from a cock fed the basal diet. Seminiferous tubules show orderly maturation of germinal cells. HE stain. $\times 400$.

Fig. 2. Testis from a cock fed the diet supplemented by $1000 \mathrm{ppm} \mathrm{Zn}$. Seminiferous tubules show various stages of spermatogenesis. Spermatozoa present in large percentage of the tubules. HE stain. $\times 400$.

Fig. 3. Testis from a cock fed the diet supplemented by $4000 \mathrm{ppm} \mathrm{Zn}$. Seminiferous tubules diminished in diameter. Spermatids and spermatozoa are completely absent. The tubules lined by Sertoli cells and spermatogonia. Interstitial cells are increased in number. HE stain. $\times 400$.

Fig. 4. Testis from a cock fed the basal diet after the recovery period. Note the complete stages of spermatogenesis and uniform tubular structure. There appears to be improved as compared with Fig. 1 . HE stain. $\times 400$. 

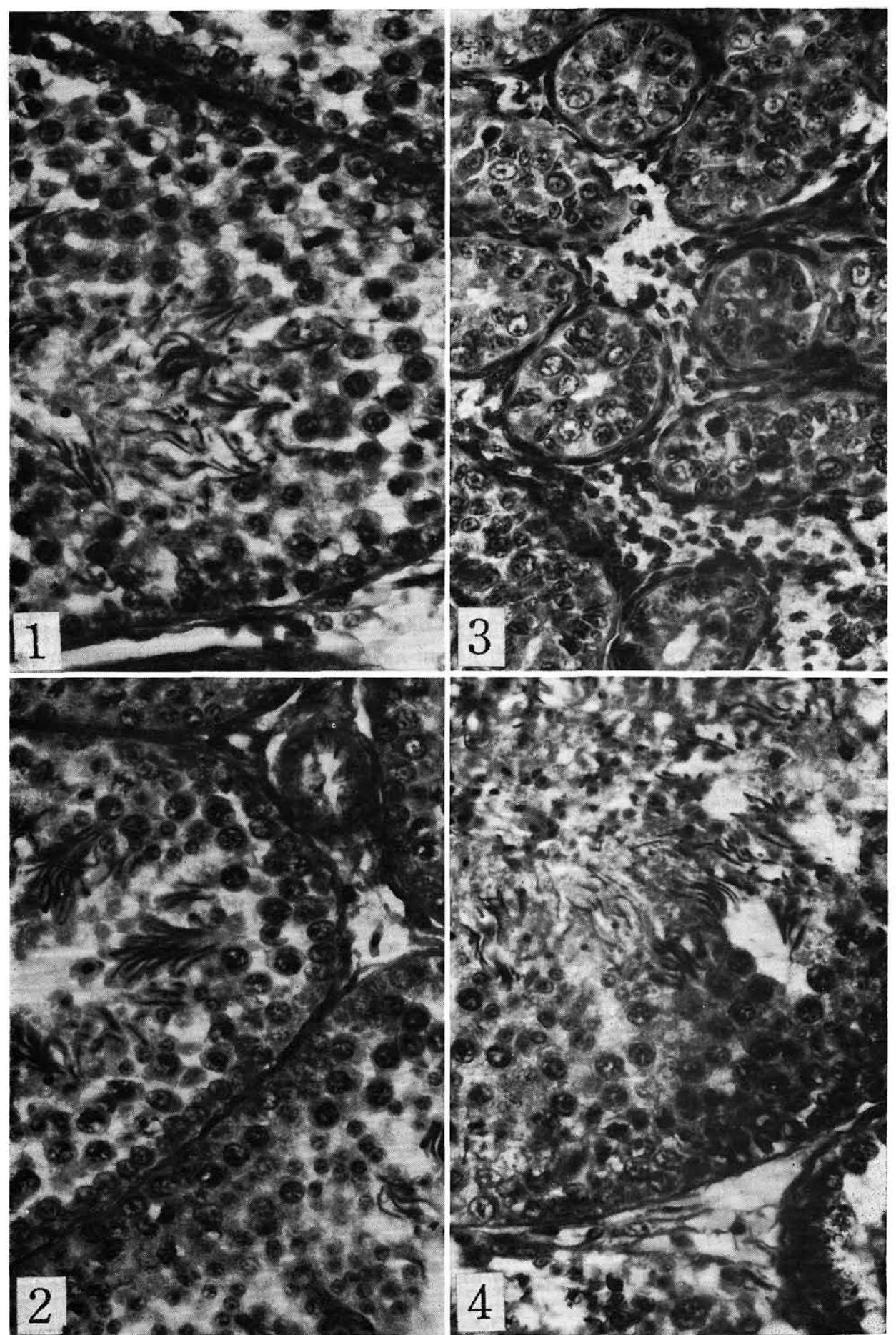

Histological Effects of Zinc in the Cocks 


\section{Explanation of Plate IV}

Fig. 5. Caudal lobe of adenohypophysis from a cock fed the basal diet. Acidophils are numerous and uniformly granulated stained with orange $G$ and acid fuchsin. Basophils have also numerous granules stained with methyl green and the cell boundaries are well defined. Matsuo tetrachrome stain. $\times 400$.

Fig. 6. Caudal lobe of adenohypophysis from a cock fed the diet supplemented by 1000 ppm $\mathrm{Zn}$. Acidophils are increased in number and size. Basophils have normal appearance. Matsuo tetrachrome stain. $\times 400$.

Fig. 7. Caudal lobe of adenohypophysis from a cock fed the diet supplemeted by $4000 \mathrm{ppm}$ $\mathrm{Zn}$. Note increased severity of regressive changes in acidophils and basophils. Basophils are remarkably decreased and poorly granulated and their nuclei showed pyknosis. Matsuo tetrachrome stain. $\times 400$.

Fig. 8. Cephalic lobe of adenohypophysis from a cock fed the basal diet. Amphophils and basopliils are numerous and granulated. Matsuo tetrachrome stain. $\times 400$.

Fig. 9. Cephalic lobe of adenohypophysis from a cock fed the diet supplemented by 1000 ppm $\mathrm{Zn}$. Amphophils increased in number, and have numerous granules stained intensely with acid violet. Basophils have the normal appearance. Matsuo tetrachrome stain. $\times 400$.

Fig. 10. Cephalic lobe of adenohypophysis from a cock fed the diet supplemented by 4000 ppm $\mathrm{Zn}$. Basophils decreased in number and size and their nuclei showed pyknosis. Amphophils are degranulated. Compare with Figs. 8 and 9. Matsuo tetrachrome stain. $\times 400$. 

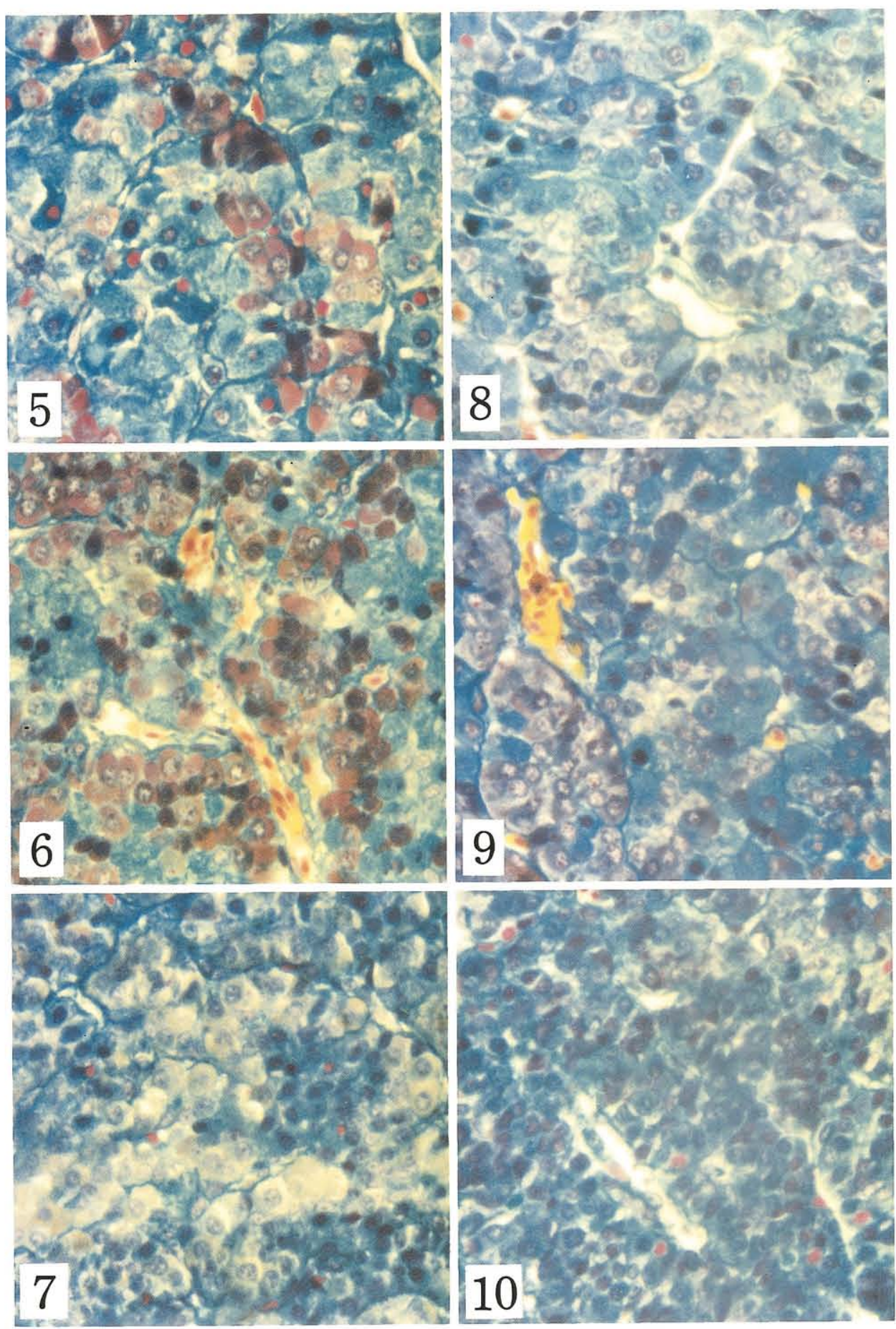

Histological Effects of Zinc in the Cocks 


\section{Explanation of Plate V}

Fig. 11. Adrenal from a cock fed the basal diet. Cortical areas stain with Sudan black, while medullary regions are colorless. Sudan black stain. $\times 100$.

Fig. 12. Adrenal from a cock fed the diet supplemented by $1000 \mathrm{ppm} \mathrm{Zn}$. Note the size of cortical area. Sudan black stain. $\times 100$.

Fig. 13. Adrenal from a cock fed the diet supplemented by $4000 \mathrm{ppm} \mathrm{Zn}$. Note the hypertrophy of the cortical mass. Compare with Figs. 11 and 12 . Sudan black stain. $\times 100$.

Fig. 14. Pancreas from a cock fed the basal diet. The acini filled with zymogen granules are noted. HE stain. $\times 400$.

Fig. 15. Pancreas from a cock fed the diet supplemented by $4000 \mathrm{ppm} \mathrm{Zn}$. Well developed fibrous tissue are noted. HE stain. $\times 400$. 


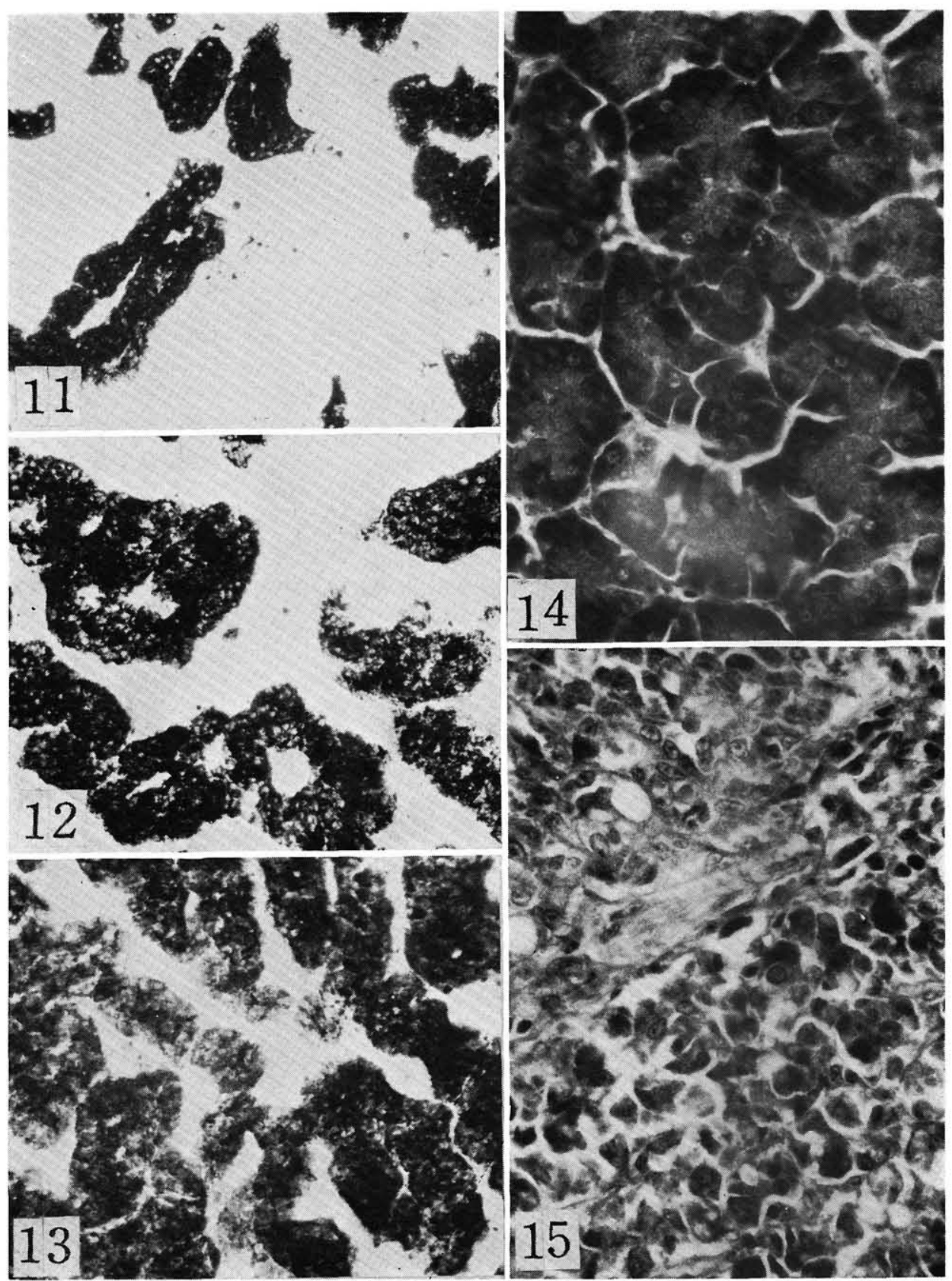

Histological Effects of Zinc in the Cocks 